\title{
DIGITALIZACE JAKO FAKTOR V KONVERGENCI PAMĚŤOVÝCH INSTITUCÍ
}

\author{
Michal Lorenz
}

Digitální informace jsou stále samozřejmější součástí vědecké práce, i své výsledky prezentuje věda veřejnosti stále častěji v digitální podobě. Významnou roli v komunikaci odborných i popularizačních informací sehrávají portály a databáze elektronických zdrojů, repozitáře, digitální knihovny a digitální archivy. Tento vývoj reflektují i odborníci uplatňující své znalosti v základních doménách informačních věd zahrnujících:

1. pragmatiku lidské komunikace včetně její augmentace,

2. management zdrojů a filtrů, a

3. interoperabilitu informačních systémů.

Hlavně odborníci v poslední doméně vytváří infrastrukturu pro šíření a sdílení informací, která je typickým projevem postupující digitalizace. Augmentací lidské komunikace vytváříme mnohačetné společenské následky, od vzniku e-infrastruktury poskytující služby a zdroje s prídanou hodnotou k proflexi lidské identity v kyberprostoru.

Našemu čtenáři na následujících stránkách přinášíme pět příspěvků, které dokládají, jak práce s digitálními informacemi prostupuje prací odborníků i společnosti. Obsah příspěvků je svojí povahou techničtější. Jednotlivé př́ispěvky ilustrují roli digitálních informací v základních doménách informačních věd. Číslo otevíráme výzkumem Ivy Zadražilové „Témata pro vzdělávací lekece seniorů v knihovnách“. Autorka se v něm dotýká potřeb seniorů v otázkách vzdělávání při práci s internetem a s informačními technologiemi. Téma reprezentuje výzkum spadající do oblasti pragmatiky lidské komunikace. Do stejné domény spadá i následující př́íspěvek Dity Malečkové, Renaty Štysové Rychtárikové a Jana Urbana s názvem „Obraz, informace, entropie،. Př́spěvek je př́kladem výzkumných snah voblasti augmentace lidské a strojové komunikace.

Následující dva odborné články reprezentují doménu managementu zdrojů a filtrů. Nejprve v př́spěvku s názvem „Digitalizace etiket standardnich šelakových desek jako nástroj pro efektivni muzejni evidenci představí Gabriel Gössel, Martin Mejzr, Michal Studničný a Filip Šír výsledky výzkumu sbírek zvukových dokumentů Národního muzea společně se systémem jejich elektronické evidence. V následujícím př́spěvku se Zdeněk Hruška rozepíše o tématu „Optické datové disky ve fondu dvou největš̌ch českých knihoven“. Předmětem zájmu se místo šelakových desek stanou optické disky zastoupené ve fondech Národní a Moravské zemské knihovny a automatizace jejich zpracování.

Poslední představený příspěvek Natálie Ostrákové, Pavlíny Kočišové a Miroslavy Beňačkové „Vývoj standardu PREMIS a možnosti jeho dalšiho vyuřití ve standardech NDK“ tematicky přispívá k doméně 
interoperability informačních systémů. Představuje standard pro zápis archivačních metadat, usnadňující práci digitálních kurátorů a aplikaci tohoto standardu v Národní digitální knihovně.

Č́slo časopisu ProInflow, které má čtenář před sebou, je odrazem současné digitalizace vědy a její pamět’ové infrastruktury. Ukazuje však ještě jeden výrazný směr dnešního vývoje - pokračující konvergenci pamět'ových institucí a jejich znalostních základů: knihovnictví (Zadražilová), muzeologie (Gössel - Mejzr - Studničný - Šír; Hruška) a (digitálního) archivnictví (Ostráková - Kočišová - Beňačková). Specializované obory pamětových institucí se potkávají pod záštitou informačních věd nad společným zájmem podpory produkce nových znalostí vědci a badateli. 